\title{
A Festa dentro da Festa: Recorrências do modelo festivo do circuito bregueiro no Círio de Nazaré em Belém do Pará*
}

Antonio Maurício Dias da Costa

UFPA

\section{O CIRCUITO BREGUEIRO COMO MODELO FESTIVO}

O circuito ${ }^{1}$ bregueiro se espalha pela cidade de Belém apresentando diferentes planos e escalas, constituindo circuitos menores ${ }^{2}$ de festas de brega dentro do circuito maior. Todos estes circuitos menores variam em seus elementos integrantes fundamentais, quais sejam, as aparelhagens ${ }^{3}$, as casas de festa e o público apreciador das festas. O exemplo dos fã-clubes de aparelhagem ${ }^{4}$, como um tipo especializado de público freqüentador do circuito bregueiro, ressalta a presença difusa do público nas festas por toda a cidade e o entrecruzamento de seus trajetos dentro do circuito festivo.

A festa, percebida em sua dimensão histórica e social ${ }^{5}$, é uma prática que está inserida no campo dos conflitos e negociações desenvolvidos na sociedade. A festa popular, na sociedade urbana e industrial, é um fenômeno complexo que abarca mediações econômicas (empreendimentos, oferecimento de bens culturais) e políticas (sistemas de troca de interesses, conflitos por poder e prestígio) ${ }^{6}$. Por conta disso, ela não pode ser considerada unicamente como expressão da alienação de um ou vários grupos sociais ou, num pólo oposto, como meramente um mecanismo de "resistência" à indústria cultural ou a esta entidade opaca que é a "cultura dominante". Trata-se de uma experiência cultural mutante ligada às diversas esferas da vida social, cuja reprodução está condicionada à multiplicidade de interesses de agentes internos e externos ao evento.

O circuito bregueiro tem sua gênese na música brega, típica de Belém do Pará, cuja história remonta aos boleros tocados nas "gafieiras" e nos "cabarés" das periferias da cidade dos anos 50 e 60. Contudo, a sua construção como um estilo musical típico inicia-se em fins da década de 70 e começos da de 80, principalmente com a difusão nas rádios locais de um estilo musical originado da mistura de elementos do bolero, do merengue e demais ritmos evocados por seus compositores.

O movimento musical do brega se desenvolveu em Belém desde a década Campos 7(2):83-100, 2006. de 80 a partir da atuação de uma indústria cultural local, que conjugava músicos, 
cantores, rádios, produtores fonográficos e estúdios de gravação. Desde então, até os dias atuais, o ritmo brega passou por algumas transformações, no que se refere à sua concepção local por parte de seus produtores, mas o seu locus privilegiado de execução e atribuição de significado, apesar de algumas modificações, permaneceu como uma constante: as festas de brega. Tais festas são resultado da somatória deste produto musical com uma rede empresarial, além de um tipo de prática de lazer que conjuga casas de festa, aparelhagens e público apreciador. A presença do circuito bregueiro nos diversos bairros de Belém e em variados eventos públicos comporta a recorrência de um modelo festivo.

De fato, o alcance do circuito bregueiro como importante prática festiva de Belém não pode ser medido simplesmente por sua dinâmica interna. Para além do universo comum das festas de brega, ele se faz presente também nos grandes festejos anuais que mobilizam a cidade como um todo, especialmente naqueles que possuem conotação religiosa, como o Círio de Nazaré. Vale ressaltar que este grande evento anual imprime uma certa mudança de ênfase das práticas festivas disseminadas pelo espaço urbano durante o período de sua ocorrência. Ao longo do mês de outubro, mês da Festividade de Nazaré, o circuito bregueiro não só permanece ativo na cidade como também se interpola no roteiro do evento religioso, adaptando-se ao "espírito festivo" dominante. Podemos dizer que o circuito bregueiro, durante estes períodos festivos, se conecta aos grandes eventos, assumindo um papel de complementação dos festejos. A festa de brega permanece como uma opção importante de lazer para os romeiros e fiéis do Círio. A atividade empresarial e a freqüentação do circuito durante estes festejos não é interrompida. Ao contrário: ela é enriquecida pelo espírito festivo que toma conta da cidade e, ao mesmo tempo, adapta-se a ele.

No caso do Círio de Nazaré, os eventos que o compõem são, em grande parte, centralizados, isto é, ocorrem em pontos mais ou menos fixos na cidade. Aliás, a marca principal do Círio, festa em movimento, é o conjunto de procissões que percorrem alguns bairros da região central da cidade (Cidade Velha, Campina e Nazaré). Somente há algumas décadas estas procissões foram complementadas pelas romarias (fluvial e rodoviária) que se estendem a distritos e à região metropolitana de Belém. Por ser composto de eventos em grande parte centralizados na cidade, o circuito bregueiro vai desempenhar meramente um papel de complemento para as escolhas de lazer dentro do período festivo. Surgem então festas de brega específicas que se tornam integrantes dos demais eventos que se desenrolam durante o grande período festivo.

É sobre a extensão do circuito bregueiro para além de seu domínio característico que versa este texto. Por se tratar de uma manifestação típica e de grande expressão na cidade de Belém, as festas de brega são elementos importantes na composição do cenário de celebração dos grandes festejos do calendário anual da cidade. Buscamos com isso apresentar um painel singular de lógicas de apropriação cultural do espaço urbano por meio da prática festiva.

\section{FESTAS DE BREGA NA FESTA DE NAZARÉ}

O Círio ${ }^{7}$ de Nazaré é o ponto alto do calendário festivo de Belém. Apesar de se tratar de um evento eminentemente religioso, as referências locais ao Círio tendem a destacá-lo como uma festividade, num sentido amplo, que envolve 
vários setores da sociedade local ${ }^{8}$. Do ponto de vista da propaganda do evento nos meios de comunicação e da divulgação turística, a presença de verdadeiras multidões durante as procissões ${ }^{9}$ e romarias na quinzena da Festividade de Nazaré ${ }^{10}$ é ressaltada como seu aspecto mais preeminente.

No entanto, o seu alcance é muito maior do que isso. Seu vigor reside na força mobilizadora sobre as diversas instâncias da vida social local. Aqui procuraremos identificar de que forma esta festividade exerce influência sobre o circuito bregueiro destacando que, pelo menos desde a última década, os eventos do circuito têm se ligado indiretamente durante este período festivo ao universo simbólico do Círio de Nazaré. Isto, aliás, é um fato já recorrente quando pensamos na presença marcante do Círio em outros aspectos da vida social local.

Num primeiro momento faremos uma breve apresentação do Círio, ressaltando sua abrangência na cidade enquanto período festivo. Em seguida será demonstrada a relação entre circuito bregueiro e Festividade de Nazaré, como resultado da abrangência do Círio na cidade e ampliação das atividades do circuito para além das suas fronteiras. A partir deste ponto, será possível esboçar algumas considerações finais.

\section{ABRANGÊNCIA SOCIAL DO CÍRIO DE NAZARÉ}

Mais de um autor que se dedicou ao estudo desta festividade ressaltou esta presença abrangente do Círio na sociedade local. Para Alves, em seu célebre trabalho sobre a festividade religiosa,

“[o] Círio e a Festa de Nazaré são importantes manifestações do corpo social, pois ao mesmo tempo em que revelam o sistema hierarquizado que caracteriza o sistema social, permitem uma investigação das relações sociais consagradas na performance ritual, além de indicarem caminhos para uma investigação entre os diversos campos de poder, através da dimensão ideológica e simbólica" (Alves 1980: 14).

Para ele, neste evento religioso, o seu conjunto de rituais, suas procissões, romarias e demais festejos são reveladores do tipo de relações presentes na sociedade envolvente, considerando também as disputas de poder envolvidas na festa, bem como suas dimensões ideológicas e simbólicas. A estrutura hierarquizada dos participantes da procissão matinal do segundo domingo de outubro, especificamente no interior da corda dos promesseiros (onde vão autoridades políticas, eclesiais e representantes da elite), constitui para Alves a principal metáfora de uma ideologia de "comunidade", de equilíbrio entre as classes. Este equilíbrio é proporcionado pelos valores religiosos mais genéricos, que "neutralizam" as diferenças e mantêm em harmonia aparente (pela manutenção da "ordem social", isto é, pela permanência da hierarquia na festa) "uma sociedade que só aparentemente está em equilíbrio" (Alves 1980: 105).

Num trabalho mais recente, que se concentra no estudo das características da "festa à brasileira", Amaral (1998) ressalta que o Círio 
“(...) é um fato social total no mais pleno sentido, pois mobiliza todas as instituições sociais da cidade e é possível notar que a festa move e transforma não apenas os espíritos humanos, mas também a sociedade e a economia" (Amaral 1998: 268).

Nesse sentido, a festividade vem a transcender seus limites religiosos para se imprimir como uma marca cultural, com efeitos importantes na alteração do cotidiano dos moradores da cidade em seus diversos aspectos. Para reforçar esta afirmação, Amaral cita um manifesto divulgado pela Diretoria da Festa de Nazaré em 1974, que ressalta a importância dos outros papéis desempenhados pelo Círio para além do seu caráter religioso, tais como o recreativo, o turístico e o educativo.

A presença marcante de turistas e romeiros vindos do interior do estado e de outras regiões do país, os preparativos das famílias para o almoço do Círio e para a recepção de parentes e amigos oriundos de outras cidades, os problemas no trânsito da cidade por conta do fechamento de ruas para procissões e demais eventos, as evocações constantes da festividade na mídia local e os demais eventos que ocorrem na cidade em torno do Círio são algumas das alterações importantes do cotidiano da cidade e adjacências, dentre várias outras, que se evidenciam neste período.

De acordo com Maués (2000), as implicações econômicas da festividade nazarena na sociedade local desempenham papel importantíssimo. Setores como comércio, indústria e serviços obtêm acréscimos relevantes em suas atividades e seus ganhos neste período. Com base em uma pesquisa do DIEESE de 1999, este autor destaca alguns números importantes da movimentação da economia local durante o período: gasto de $32 \%$ da renda dos moradores da cidade com artigos ligados à festividade: almoço do Círio, bebidas, vestuário, lazer e promessas; previsão para gastos de $50 \%$ dos turistas que variam entre 100 a 400 dólares, durante a permanência em Belém; faturamento de 9 milhões de reais com os gastos de turistas brasileiros e estrangeiros.

Mas, antes de tudo, devemos considerar o Círio, tal como se apresenta nos dias de hoje, com seu aspecto abrangente e mobilizador da sociedade local, como o resultado de um processo histórico de consolidação da presença religiosa católica na Amazônia, mediado pelo Estado (colonial, imperial, republicano) e vivenciado pela população local.

De acordo com Maués (2000), esta festividade está ligada aos círios que eram feitos em Portugal desde o século XVII, realizados por corporações religiosas no mês de setembro, que se dirigiam à Vila de Nazaré. No Brasil, existem algumas informações de que os primeiros círios ocorreram na Vila da Vigia (hoje município), no estado do Pará, desde o século XVII. No entanto, o primeiro Círio a se ter informações oficiais da sua ocorrência se deu em setembro de 1793, em Belém do Pará.

O mito de origem da procissão remonta à tradição portuguesa de imagens "achadas" por milagre em lugares ermos $^{11}$. O seu aparecimento milagroso acaba por ter equivalência com o poder atribuído à santa de conceder graças milagrosas aos fiéis, obtidas através de promessas ${ }^{12}$.

O ponto alto da celebração destas santas ocorre quando das visitações dos fiéis aos santuários, das romarias 
pela irmandade de Nazaré teve apoio do governo local desde o seu início. Ao longo do tempo, a procissão foi assumindo a feição presente por conta das mudanças e de acontecimentos específicos: acréscimos de elementos novos à procissão (corda, carros alegóricos); aumento do número de procissões e romarias; criação do arraial com feira de produtos regionais e parque de diversões; conflitos envolvendo autoridades eclesiásticas, questões políticas, dentre outros ${ }^{13}$; aumento considerável do número de devotos da santa, ao ponto de esta ser reconhecida como a "Padroeira dos Paraenses"14.

É considerável a quantidade de trabalhos que têm o Círio de Nazaré como temática. Do ponto de vista histórico, podemos citar especialmente as obras de Vianna (1904), Cruz (1952 e 1967) e Rocque (1981) como as que fornecem um panorama detalhado dos desdobramentos históricos da festa. Do ponto de vista de um enfoque sociológico, destacam-se os trabalhos de Mombelli (1976) e Moreira (1971) e, sobretudo, a obra de Alves (1980), que reuniu todas as contribuições anteriores. Destas obras, vale destacar a importância do ensaio de Moreira (1971), que se propõe a apresentar uma visão geo-social do Círio de Nazaré.

Em seu estudo "geo-social" do Círio, Moreira ressalta o papel deste evento na criação de um forte "intercurso demográfico" entre a capital e o interior do Estado. De início, os círios do século XVIII e início do XIX seriam marcados por um deslocamento de Belém para fora da cidade: a procissão saída do Palácio do Governo da Província se dirigia à ermida da santa, erguida às margens do Igarapé Murutucu (onde mais tarde viria a ser construída a Basílica de Nazaré). Nesse ínterim, surgem diversas procissões com nome de Círio em várias cidades do interior do estado, celebradas geralmente no segundo semestre e principalmente nos últimos meses do ano ${ }^{15}$.

Em seguida, já em meados do século XIX, o processo de crescimento da cidade termina por englobar a região do Murutucu, transformando-a em área urbana, correspondente à Paróquia de Nossa Senhora de Nazaré, com sede em sua matriz ${ }^{16}$, construída em substituição à ermida inicial. Desse modo, ao longo do século XIX a procissão do Círio viria a assumir um caráter eminentemente urbano. Ao mesmo tempo, com o aumento do fluxo de devotos vindos do interior para a procissão, segundo Moreira, o movimento se inverte, de fora para dentro da cidade.

Além disso, considerando os acréscimos mais recentes aos eventos oficiais da festa de Nazaré, o trajeto da imagem pela cidade tem sido ampliado, alcançando a região metropolitana (Romaria Rodoviária, a partir do município de Ananindeua) e um distrito da cidade (Icoaracy, de onde parte a Romaria Fluvial). Mais ainda, o fluxo de devotos e turistas tende a se ampliar a cada ano, a partir de outros estados brasileiros e mesmo de países estrangeiros.

\section{A FESTA DENTRO DA FESTA: DO ARRAIAL AOS BAILES DE ROMEIROS}

Outra questão importante levantada pelo trabalho de Moreira é o emprego da metáfora do Círio como um “Carnaval Devoto", proposta pelo romancista Dalcídio Jurandir (1960) e que mais tarde viria a ser utilizada por Alves como o título de seu trabalho. Com esta metáfora Moreira destaca o entrelaçamento de traços profanos e sagrados na 
festa de Nazaré, que podem ser facilmente visualizados fora (nos eventos festivos que ocorrem na órbita do Círio) e dentro da festa, como os carros alegóricos ${ }^{17}$, o comportamento dos fiéis na procissão, que mescla contrição e informalidade, e a presença do "Arraial de Nazaré", combinação de feira de produtos regionais com parque de diversões, dentre outros.

De acordo com Alves (1980), esse sentido de "carnavalização" assumido por alguns elementos da Festa de Nazaré está em conformidade com o espírito de devoção do período. Isto é possível, segundo este autor, considerando-se as forças de neutralização e conciliação das diferenças e desigualdades sociais presentes em eventos religiosos.

Na visão de Alves, ao lado dos atos litúrgicos do Círio, destacam-se os momentos de encontro (visitas dos parentes e amigos do interior e de outros estados, por exemplo), de solidariedade (exemplificada por gestos de amizade entre desconhecidos na procissão) e de neutralização das diferenças (isto é, a hierarquia social é mantida na festa, mas é embotada pelos valores religiosos mais genéricos que a envolvem). É desse modo que deve ser entendida a metáfora da carnavalização de Alves, considerando o espírito de comunidade instalado nos quinze dias da festividade e presente nos seus locais de celebração, semelhante àquele presente no carnaval brasileiro, tal como discutido por DaMatta (1999) ${ }^{18}$. A idéia de carnavalização assume importância não somente pela criação de laços comunitários "perdidos" (Alves 1980:87) e revividos na festa, mas também no que se refere ao próprio espírito festivo instalado na cidade durante a quinzena nazarena.

O Arraial de Nazaré pode ser considerado, de um ponto de vista histórico, como o local privilegiado da celebração profana do Círio. Desde o primeiro Círio, em 1793, o Governo Provincial tomou a iniciativa de instalar em frente à capela de Nossa Senhora de Nazaré, num espaço denominado arraial ${ }^{19}$, uma feira de produtos regionais (Maués 2000:39) ${ }^{20}$.

A presença e o funcionamento do arraial desde então corresponde a uma espécie de "festa dentro da festa", algo bem parecido com a descrição de Del Priori (1994:43-62) do papel desempenhado pelos cortejos e procissões nas festas religiosas do Brasil colonial. Segundo a autora, as danças, as fantasias, os carros alegóricos nestas procissões assumiam vida própria e significado particular no interior da festividade maior.

Na descrição de Moura (1997:97-100), o funcionamento do arraial nazareno no século XIX não se resumia à mera exposição e venda de "produtos regionais". Além das barracas fixas, a movimentação do público era acompanhada pelo comércio ambulante, por jogos, pelas danças coletivas negras, indígenas (lundum, chorado, cateretê, dança do bagre, mandu-sarará e bambiá) e européias (dança das saloias e dança das camponesas), pelas apresentações musicais (normalmente apresentações de bandas) e teatrais ${ }^{21}$.

O trabalho de Alves data do final da década de 70, mas nele o autor ainda descreve o Arraial de Nazaré como “uma grande feira comunitária no próprio sentido em que se diferencia da sociedade que está lá fora" (1980:87). O arraial, de acordo com a idéia de uma "festa dentro da festa", representa para Alves o ambiente típico em que a ideologia de comunidade vivenciada durante o Círio é exercida plenamente. Nele, segundo o autor, os contatos são diretos e "laços de comunidade" são criados. 
Analisando os croquis do Arraial de Nazaré dispostos nos anexos do livro de Alves ${ }^{22}$, podemos perceber que até o final da década de 70 este era ainda, em grande parte, uma feira de exposições, mesclada com lanchonetes, barracas de comidas regionais com espaço para shows, espaços recreativos e uma área funcionando como parque de diversões. Num capítulo sobre o arraial nazareno, Alves ressalta que, ao lado das demais áreas de lazer, a feira de exposições procura apresentar uma "idéia do desenvolvimento de Belém", com os produtos de instituições públicas e empresas privadas.

Podemos dizer que este caráter de feira de exposições do arraial passou a ser modificado quando este foi deslocado para outra área contígua à Basílica, dando lugar à construção do Conjunto Arquitetônico de Nazaré (conhecido localmente pela sigla CAN), em 1981. No lugar do antigo arraial foi construída uma "Praça Santuário". A praça é cercada por um gradil de ferro e no seu centro está localizado o nicho da imagem de Nossa Senhora, que lá permanece durante a quinzena do Círio.

Com a mudança da área do arraial, o parque de diversões passou a ser a principal atração da festa noturna. A cada ano, empresas especializadas no ramo de equipamentos de parques de diversões são contratadas para se instalar no arraial. Aos poucos, os estandes de empresas públicas e privadas foram sendo substituídos pelos "brinquedos" do parque, restando somente as lanchonetes e barracas de venda de comidas típicas.

Cada vez mais o arraial desempenha o papel de fonte arrecadadora para a Diretoria da Festa, de modo a contribuir com fundos para a realização do próximo Círio e garantir o financiamento das obras sociais mantidas pela Paróquia de Nazaré. Nesta entrevista concedida pelo coordenador da Diretoria da Festa de Nazaré na gestão 2001-2002, é enfatizada a função do arraial:

“É gerido pela Diretoria da Festa para garantir recursos para a festividade. Não só para a festividade, mas as obras sociais da Paróquia de Nazaré. Você vê que eu tenho três creches que eu mantenho (...). Só uma delas tem 400 crianças. (...) Eu realizo a festa, eu tenho despesas com a festa, mas o dinheiro que eu vou gastar eu vou aplicar exatamente nas obras sociais. (...) O parque de diversões eu cedo, alugo e tenho uma contrapartida. (...) Eu também cobro aqui dentro pras pessoas, por exemplo, vender pipoca, vender não-sei-quê, isso tudo é revertido pras obras sociais. Se inscrevem aqui, naturalmente. Se a pessoa estiver sem a credencial, não passa que a segurança sabe. É o modo como você tem correto de angariar recursos" (João José da Silva Maroja, Coordenador da Diretoria da Festa de Nazaré - Entrevistado em novembro de 2002).

As referências em primeira pessoa nesta fala, na verdade, aludem à atuação da Diretoria da Festa como uma instituição civil, junto à Igreja Católica. Como se observa no relato, o espaço do arraial tem assumido cada vez mais o papel de parque de diversões, complementado pelas lanchonetes, bares e barracas de venda de comidas típicas, que constituem fontes importantes de arrecadação para a diretoria da festa.

O amplo parque de diversões passou a ocupar o lugar dos estandes de exposição de instituições (como Governo do Estado, Universidade Federal do Pará, Banco da Amazônia, Superintendência de Desenvolvimento da Amazônia, Federação das Indústrias, dentre outras) existentes nos anos $70^{23}$. Isto, por seu turno, contribuiu para uma "homogeneização" do público, que em grande parte se dirige para o arraial em busca dos "divertimentos" do parque, após uma provável visita à Basílica, ao nicho da santa e aos arredores. 
Com este formato, a "festa dentro da festa" que o arraial de Nazaré continua a ser pouco evoca a idéia de uma "comunidade" restaurada durante a quinzena do Círio, como propunha Alves nos anos 70. Isto também é resultado do aumento da oferta de eventos "profanos" na cidade durante este período festivo, com características diversas. Estes "outros" eventos passaram a fazer parte do calendário "não oficial" da festividade de Nazaré, como os já citados Auto do Círio e Festa da Chiquita. Dentre os variados eventos inseridos não oficialmente na programação da quinzena do Círio, destacam-se as festas típicas do circuito bregueiro, que se apresentam de formas diferentes nas margens da festividade religiosa.

Um exemplo importante deste tipo de "festa dentro da festa" no Círio de Nazaré, relacionado ao circuito bregueiro, é a festa do Sindicato dos Estivadores do Estado do Pará. A festa que hoje é realizada desde a quintafeira anterior ao segundo domingo de outubro está condicionada à homenagem com fogos de artifício que faz esse sindicato quando da "passagem da santa" na região portuária. De acordo com as informações obtidas em conversas informais com membros deste sindicato, a homenagem teve seu início em 1945, quando dois trabalhadores do porto (os senhores Frederico Conceição e Benevenuto Lobato) fizeram um pedido à Nossa Senhora de Nazaré de melhoria de suas condições de trabalho. A promessa oferecida em troca do alcance da graça seria a realização de uma homenagem com fogos de artifício à passagem da santa próximo ao local de trabalho dos estivadores ${ }^{24}$.

Com a graça alcançada, no ano seguinte, integrantes do sindicato contrataram um "fogueteiro" da cidade de Vigia (José Palheta) para confeccionar os fogos para a homenagem. Os recursos foram obtidos através de coleta espontânea dos trabalhadores. A idéia era fazer um show pirotécnico que, durante o dia, pudesse atrair a atenção dos fiéis na procissão pelo barulho e pela quantidade dos fogos ${ }^{25}$. Aliás, esta tem sido uma marca dessa homenagem que é atualmente considerada a mais importante em todo o percurso da procissão. Exemplo do prestígio da homenagem é a parceria existente nos dias de hoje entre o sindicato e uma empresa de comunicação local (Organizações Rômulo Maiorana), complementada pela contribuição periódica dos estivadores ${ }^{26}$ para a compra de material, confecção e instalação dos fogos.

Antecedendo esta homenagem, o sindicato passou a promover desde três dias antes do Círio uma festa de confraternização dos amigos e parentes dos trabalhadores do porto. A festa que no seu início, quando do surgimento da homenagem, era um evento particular e de pequena expressão, passou nos últimos anos a assumir grande importância na programação festiva não oficial do Círio.

A festa se inicia na quinta-feira anterior ao domingo do Círio, sendo instalada uma aparelhagem na Praça dos Estivadores, local onde são armadas as estruturas dos fogos para a homenagem. Nos anos anteriores, a aparelhagem que se apresentava nesta festa era de propriedade do sindicato. Já em 2003 (quando foi realizada a pesquisa), uma aparelhagem particular havia sido contratada para sonorizar a festa. Vale dizer que tanto a aparelhagem do sindicato, quanto aquela contratada em 2003 são equipamentos de pequeno porte, porque para os organizadores deste evento não seria interessante atrair um número muito grande de participantes para a festa. Isto sem dúvida ocorreria se aparelhagens famosas da cidade como Pop Som, Príncipe Negro, Rubi e Tupinambá, dentre outras, fossem contratadas para a festa. 
Mas a festa que acontece na Praça dos Estivadores, localizada no trajeto da procissão religiosa que ocorre na noite de sábado (Transladação) e no domingo de manhã (o Círio propriamente dito), constitui uma típica festa de brega. Trata-se de um evento anual que transforma aquela praça, praticamente vazia de ocupantes durante o ano, em um lugar festivo importante na véspera do início do Círio. Isto equivale ao que sugere Sanchis (1992:141) acerca de uma das possibilidades da festa (tais como as festas religiosas): transformar espaços de "sociabilidade trivial e desvalorizada", como praças, ruas, passeios, em pontos intensos de contatos e trocas. A festa dos estivadores, durante a quinta e a sexta-feira, segue o modelo do circuito bregueiro: aparelhagem, bregas de sucesso (acompanhados de outros ritmos dançantes selecionados pelo DJ), venda de cerveja, mesas e cadeiras dispostas em torno do "salão" e a dança como a tônica da festa.

Excepcionalmente no sábado, antes da Transladação, e no domingo, depois da procissão do Círio, a aparelhagem que permanece na Praça dos Estivadores faz uma sonorização específica de músicas religiosas variadas. Já durante as procissões citadas, a aparelhagem toca os hinos religiosos típicos do Círio, contribuindo dessa forma para o evento. Ao mesmo tempo, a festa de brega iniciada na quinta-feira continua no final de semana na Sede Campestre dos Estivadores, localizada na região metropolitana de Belém. Aliás, esta sede campestre faz parte do circuito de festas de brega, que ocorre sempre no domingo à tarde nos diversos balneários nos arredores da cidade. Isto indica, portanto, alguma inserção dos organizadores da festa dos estivadores no circuito bregueiro, habilitando-os a reproduzir este modelo festivo na confraternização dos trabalhadores do porto originalmente ligada ao Círio de Nazaré.

O mesmo ocorre com as festas de vizinhança que pululam nas periferias da cidade na véspera da procissão principal, no sábado à noite, e durante a tarde e a noite do domingo do Círio. Esta é uma prática mais recente de celebração festiva do Círio que tem crescido de importância na cidade nos últimos anos. À primeira vista, estes eventos parecem fazer parte de uma programação específica, com um propósito festivo particular. No entanto, durante a pesquisa de campo, foram vários os momentos em que participantes destas festas justificavam para mim a sua ocorrência por se tratar de uma comemoração do Círio. Aliás, numa destas conversas, o interlocutor cometeu um ato falho e me disse que a festa de sua rua era uma comemoração do Natal. Logo em seguida ele corrigiu a informação e situou a data festiva correta.

Isto me pareceu muito significativo, especialmente pelas alusões comuns durante o Círio, tanto por grande parte da população de Belém como pela mídia local, de corresponder a festa religiosa ao "Natal dos paraenses". Mas se no Natal a celebração é tipicamente familiar, é possível que o "poder aglutinador do Círio", conforme proposto por Alves (1980:102), exerça alguma ação nas redes de vizinhança de modo a mobilizar seus festeiros ${ }^{27}$ amadores a fazer contato com donos de aparelhagens e organizar festas de brega.

As festas de vizinhança do Círio que presenciei em bairros como Guamá, Jurunas e Canudos eram em grande parte feitas em ruas estreitas, vilas, em que estavam instaladas aparelhagens de médio porte acompanhadas de certa infra-estrutura para a festa na rua: algumas mesas e cadeiras, iluminação, tabuleiros de venda de comidas típicas e um local reservado para a venda de cerveja. Mas em nenhum dos casos encontrei as ruas fechadas para a 
cobrança de entrada aos participantes. Talvez isto não tenha ocorrido por assumirem estas festas um sentido pleno de confraternização de vizinhança, quando a família, após a intimidade do almoço do Círio, com seus parentes e amigos, encontra e celebra a data festiva com seus vizinhos na rua de sua casa.

No Círio de 2003 pude constatar a presença em diversos pontos da cidade de faixas típicas do circuito bregueiro anunciando várias festas de brega que viriam a ocorrer no final de semana da procissão principal. As faixas que anunciavam as festas de vizinhança concorriam por espaço em diversos pontos da cidade com o grande número de anúncios de festas de brega em casas de festa. A presença dos anúncios atesta o vigor com que cada vez mais o circuito bregueiro adentra o calendário de eventos do Círio. Algumas destas faixas, no Círio de 2003, faziam homenagem a Nossa Senhora de Nazaré em nome de casas de festa, festeiros e artistas de brega, como a que segue:

\section{Clube Ipanema e Naldo "o malucão" (Promoção e Eventos) Saúdam a Virgem de Nazaré (Xeiro Verde, Palácio dos Bares, Brega do Carrossel, Big Brother)}

Esta faixa estava disposta nas proximidades do Mercado de Carne do bairro de São Braz e permaneceu naquele local durante toda a quinzena do Círio. Um elemento da faixa que não pôde ser reproduzido aqui é a ilustração da imagem de Nossa Senhora que acompanhava a mensagem de saudação. As homenagens à Virgem de Nazaré através de faixas são uma constante no percurso da procissão, que vai da Catedral da Sé à Basílica de Nazaré, bem como no caso da romaria rodoviária em direção à região metropolitana. Agora, às homenagens feitas por repartições públicas e estabelecimentos comerciais somam-se componentes típicos do circuito bregueiro: três casas de festa (Clube Ipanema, Palácio dos Bares, Brega do Carrossel), um festeiro profissional (Naldo, "o malucão") e duas bandas de brega (Xeiro Verde e Big Brother).

A partir das faixas pude verificar a ocorrência de variados tipos de festas de brega durante o final de semana do Círio (segundo final de semana de outubro). Dentre estas festas podemos selecionar alguns tipos básicos: Bailes de Romeiros, Bailes da Saudade do Círio (podendo ser realizados na rua ou em casas de festa), Festas de Balneários, Festas de Vizinhança, Festas em locais públicos, Festas da Ressaca e Festas de despedida dos romeiros.

Em meio a esta variedade, detalharemos os tipos de festa mais importantes. Os Bailes de Romeiros são festas de brega comuns que procuram atrair o público oriundo do interior do estado que se instala nas casas de parentes durante o Círio. No entanto, o conteúdo destas festas é o mesmo das festas típicas do circuito bregueiro, já que seu público regular se faz presente também nestes eventos. O mesmo ocorre com os Bailes da Saudade do Círio, que procuram associar na sua propaganda o evento com o período festivo, de modo a apresentar uma opção de lazer durante a festa religiosa.

As festas de balneários geralmente ocorrem aos domingos durante o dia nas sedes campestres de sindicatos e associações profissionais, localizadas geralmente na Região Metropolitana. Já as festas de vizinhança podem ocorrer por diversos motivos ${ }^{28}$, mas são mais freqüentes durante as festas juninas. As festas de brega em locais 
públicos não parecem ser muito comuns, a não ser em casos como aniversários de programas locais de Rádio e de TV (em praças públicas) e nos comícios de políticos em período de campanha eleitoral ${ }^{29}$.

No entanto, eventos como uma apresentação da aparelhagem PopSom no sambódromo local ("Aldeia Cabana") em 2003 e a Festa dos Estivadores são exemplos do tipo de festa que ocorre na véspera da procissão principal do Círio. Já as festas da "ressaca" e as de "despedida dos romeiros", seguindo também o modelo típico das festas de brega, acontecem na segunda-feira seguinte à procissão dominical, respectivamente pela manhã e à noite.

Em todos estes eventos percebe-se claramente a evocação do Círio como uma estratégia de propaganda, destinada a atrair público. Mas, além disso, esta evocação representa também uma adequação do circuito bregueiro àquele momento festivo, quando grande número de turistas está na cidade e muitos deles nem sempre reconhecem as festas de brega como uma opção de lazer típica de Belém.

As festas de brega são um produto de lazer vendido internamente, direcionado para o público local, apesar dos projetos e carreiras de alguns artistas focalizarem a expansão do público apreciador da música brega para além do Estado do Pará e da Região Norte.

Em contrapartida, o Círio de Nazaré, desde há várias décadas, é tomado, por seus organizadores e pelos administradores públicos, como um instrumento de atração turística e de veiculação de uma imagem particular da cidade de Belém e do Estado do Pará para fora. Por estas questões, a inserção do circuito bregueiro entre as opções festivas não religiosas do Círio representa uma oportunidade de aliança entre um modelo festivo local e outro, assentado em sólido peso histórico e colossal força simbólica, que produz uma representação da sociedade local que é levada para fora da região.

As expectativas dos empresários do circuito bregueiro de grandes lucros com as festas de brega no "final de semana do Círio" (que se estende de quinta-feira à segunda-feira seguinte) se aliam ao "espírito festivo" que toma conta da cidade na véspera e durante o grande evento religioso que mobiliza a cidade como um todo. A habilidade dos empresários do circuito bregueiro em adequar os seus eventos ao período festivo em questão se revela não somente pela realização de bailes de romeiros, festas da ressaca e festas de despedida do Círio, mas também pela menção da festa religiosa em todos os anúncios de eventos do circuito. Estas menções ao Círio, por sua vez, se fazem sentir nos anúncios de festas nas casas de brega, passando pelas casas de show, balneários e chegando às festas de vizinhança, realizadas na rua.

De todo modo, o circuito bregueiro permanece na "periferia" dos festejos oficiais do Círio de Nazaré. Isto acontece tanto por este não fazer parte da programação festiva reconhecida como ligada tematicamente ao Círio (como é o caso do Arraial de Nazaré, do Auto do Círio e da Festa da Chiquita), como pelo fato de estar espalhado pelas periferias da cidade. No entanto, cada vez mais sua presença se faz sentir nestas margens da festa de forma mais especializada, como uma alternativa de lazer para os participantes da dimensão "profana" da festa. As festas de brega tendem a se tornar uma das modalidades de lazer típicas do período do Círio, mais uma das variações do "Carnaval Devoto". 


\section{CONSIDERAÇÕES FINAIS}

A feição atual das "franjas" da Festa de Nazaré, intercaladas por expressões do circuito bregueiro, representa, ao mesmo tempo, uma ampliação do leque de opções festivas dentro do próprio circuito e uma sensível mudança na disponibilidade de lazer para os romeiros e demais participantes da festividade religiosa. $\mathrm{O}$ "carnaval devoto" tende a assumir novas feições, considerando-se a dinâmica auto-reprodutiva da cultura de massa local e da consolidação de um modelo festivo de caráter fortemente popular.

A festa de brega em Belém está a meio caminho entre a cultura de massa (produzida localmente) e as práticas culturais de seus freqüentadores. Ela não se apresenta no sentido clássico enquanto uma ruptura temporal por excelência. Até certa medida, a festa de brega se confunde com o cotidiano da cidade, com suas festas que vão de quinta à segunda-feira seguinte ${ }^{30}$ de cada semana. Ao mesmo tempo, ela está dotada de um grau de flexibilidade que lhe permite adequar-se aos pontos altos do calendário festivo da cidade.

De todo modo, eventos do circuito são quase sempre apresentados por seus organizadores como "únicos", ressaltando a sua novidade e o acréscimo de atrações (equipamentos novos da aparelhagem, presença de artistas de brega, a primeira apresentação de uma aparelhagem em determinada casa de festa etc.), de modo a chamar a maior quantidade de pessoas possível. E mesmo do ponto de vista do público, a participação nestes eventos, tomada como uma opção de lazer, destoa do cotidiano de trabalho e das obrigações da rotina diária. O sentido construído localmente para a festa do circuito bregueiro reside fundamentalmente nestas condições particulares.

Além destas questões, é fato que a construção do modelo festivo está diretamente ligada às transformações da sociedade envolvente. As festas de brega constituem um novo campo de trabalho que passou a empregar muitas pessoas nas mais diversas atividades, tanto nas casas de festa, nas aparelhagens (que são empresas familiares, mas que congregam funcionários que não fazem parte da família do proprietário), quanto profissionais free-lancers que se encarregam da organização das festas, os festeiros. Temos com isso grande número de pessoas oriundas das camadas de baixa renda da cidade que tomaram parte em atividades empresariais e passaram a se manter com elas. Da mesma forma, sobressaem-se as maneiras criativas pelas quais os freqüentadores das festas passaram a se inserir no circuito bregueiro, quer nos bailes da saudade, quer nos fã-clubes.

Originalidade e novidade no formato dos eventos, empreendimento econômico e a partilha de novas formas de sociabilidade no campo do lazer, como traços típicos do circuito bregueiro, associam-se à multiplicidade de sentidos abarcados pela excepcionalidade do Carnaval Devoto. Por este movimento se percebe a vitalidade do Círio enquanto festa urbana de caráter sumamente popular, periodicamente remodelada com base em expressões locais massivas de sociabilidade. 
* O presente artigo corresponde, em parte, ao quarto capítulo de minha tese de doutoramento intitulada "Festa na Cidade: o circuito bregueiro de Belém do Pará", apresentada ao Programa de Pós-Graduação em Antropologia Social da Universidade de São Paulo em agosto de 2004.

1 De acordo com Magnani (1996 e 2002), circuito corresponde a uma categoria analítica que remete à presença de ordenamentos particularizados e setorizados na paisagem urbana, apresentados em múltiplos planos e escalas, em geral marcados pela oferta de serviços e práticas culturais dispersas pela paisagem urbana, mas reconhecidos como uma totalidade pelos seus freqüentadores, tais como circuitos de festas específicas, de práticas religiosas, dentre outros. Sobre o circuito bregueiro de Belém ver também Costa (2003)

2 Os circuitos das festas no interior de um bairro, das festas realizadas em casas famosas da cidade, do percurso seguido em casas de festas, ao longo de vários finais de semana, por empresas específicas de sonorização das festas, dentre outros.

3 Empresas de sonorização voltadas especialmente para a realização de festas de brega. Normalmente de propriedade familiar e administradas por famílias, as aparelhagens passam de pai para filho. Da mesma forma, suas diversas funções de gerenciamento são divididas entre os membros masculinos do núcleo familiar: a realização de contratos com casas de festa, controle financeiro, transporte do equipamento, reparo, revisão e atualização do equipamento sonoro, dentre outras. As aparelhagens são em geral classificadas como de pequeno, médio ou grande porte por meio de sua potência sonora, embora conte também para isso o valor dos contratos para festas, sua popularidade (por exemplo, a quantidade de fã-clubes que as seguem) e suas ligações com os outros empresários do circuito bregueiro: donos de casas de festa e festeiros (contratantes particulares de festas). No sentido estrito, a aparelhagem é o equipamento sonoro composto de uma unidade de controle e seu operador (o DJ), que possibilita o uso de diversos recursos e alta qualidade na emissão musical, e suas caixas de som, que comportam diversos alto-falantes e tweeters, agrupados no formato de colunas de 3 a 5 metros de altura, aproximadamente. A disposição do equipamento sonoro das aparelhagens nas festas de brega é muito parecida à das radiolas das festas de reggae do Maranhão e às equipes dos bailes funk do Rio de Janeiro.

4 Os fã-clubes são originários do hábito de acompanhar as apresentações de aparelhagens específicas desenvolvido por determinados grupos de jovens. Trata-se de uma forma de sociabilidade resultante da freqüentação às festas de brega como uma prática de lazer. Normalmente os fã-clubes surgem por conta das apresentações bem-sucedidas de uma aparelhagem num determinado bairro (principalmente as aparelhagens de grande porte), criando espaço para o aparecimento de "admiradores" desta aparelhagem, ou seja, aqueles que se mobilizam especialmente para participar das suas festas. Aparelhagens de grande e médio porte possuem aproximadamente de 30 a 50 fã-clubes cada, que se revezam participando das apresentações de "suas" aparelhagens a cada final de semana, tanto em Belém como em cidades vizinhas.

5 Sobre a importância de considerar o contexto sócio-histórico da festa, ver Isambert (1982).

6 Sobre esta questão, ver Amaral (1998).

7 A palavra Círio tem origem no latim cereus, "de cera", que pode ser tanto uma grande tocha como velas pascais de cera. Estas últimas, juntamente com outros objetos de cera levados por promesseiros, que buscam reproduzir partes do corpo humano, são recorrentes na procissão do Círio desde os seus primeiros anos.

8 Alves (1980: 102) discute a concepção do Círio como uma festa associada a uma idéia de identidade regional, pondo em relevo seu poder aglutinador e neutralizador das diferenças entre os atores. Isto se sustenta nas referências populares e midiáticas à "festa maior dos paraenses", ao Círio como "o Natal dos paraenses", à santa como "Rainha da Amazônia" e à ligação decisiva entre Círio e cozinha regional, simbolizada pelo almoço do Círio (quando parentes e amigos se reúnem após a procissão matinal do segundo domingo de outubro para consumir, dentre outros pratos, a maniçoba e o pato no tucupi).

9 Os números mais recentes dos administradores públicos locais estimam quantidade superior a um milhão e meio de pessoas na procissão matinal do segundo domingo de outubro.

10 O "Círio", festividade religiosa surgida em Belém no ano de 1793, na verdade corresponde somente às procissões mais importantes que inauguram a Festa de Nazaré, na véspera e durante o segundo domingo de outubro. A Festa de Nazaré compreende vários 
eventos religiosos, tais como: translado da imagem em carro aberto para Ananindeua (município da região metropolitana) dois dias antes da procissão principal; "Romaria Rodoviária" para o porto de Icoaracy, distrito de Belém; "Romaria Fluvial" saída de Icoaracy em direção ao porto de Belém; "Romaria dos Motoqueiros" saída do porto de Belém em direção ao Colégio Gentil Bittencourt; "Descida da Imagem", cerimônia na Basílica de Nazaré após a Romaria dos Motoqueiros; "Transladação", segunda procissão mais importante do Círio, quando no fim da tarde do sábado é conduzida a imagem da santa do Colégio Gentil à Catedral da Sé, no bairro da Cidade Velha; "Procissão matinal do Círio de Nazaré" no segundo domingo de outubro, saída da Catedral da Sé, em direção à Basílica de Nazaré, no bairro de Nazaré; "Círio das Crianças", realizado no primeiro domingo após o Círio principal; "Procissão da Festa", ocorrida no segundo domingo após o Círio principal; "Missa de Encerramento", no segundo domingo; "Fogos de Encerramento" após a missa final; "Subida da Imagem" (ao "Glória", localizado no altar principal da Basílica de Nazaré, na segunda-feira seguinte à missa de encerramento); "Missa de Despedida", realizada após a subida da imagem; Recírio, procissão final em que a imagem retorna ao Colégio Gentil, após a Missa de Despedida; "Incineração das Súplicas", em que os pedidos dos devotos depositados durante a festividade junto ao nicho da santa na praça santuário em frente à Basílica de Nazaré são queimados pelos diretores da festa de Nazaré. Ao lado destes eventos se destaca a presença do arraial, que constitui um parque de diversões montado ao lado da Basílica de Nazaré e que funciona durante os quinze dias da festividade e é gerido pela Diretoria da Festa de Nazaré. Outros eventos importantes ocorrem na cidade neste período, condicionados à presença do Círio, mas que não possuem ligação direta com a organização deste evento. Dentre eles, os mais importantes são: "Auto do Círio", espetáculo teatral encenado em movimento nas ruas do bairro da Cidade Velha dois dias antes da procissão principal e que faz uma paródia carnavalizada do Círio; e a "Festa da Chiquita", realizada na véspera da procissão principal e num trecho do seu percurso (Rua da Paz, em frente ao Teatro da Paz, à margem da Avenida Presidente Vargas), na noite do sábado para domingo. É um evento voltado principalmente ao público homossexual, em que ocorrem apresentações de cantores regionais, de grupos folclóricos, shows de travestis, dentre outros.

11 O relato do "achado" da imagem de Nossa Senhora de Nazaré em Belém remonta ao mito português referente ao achado da imagem desta mesma santa numa gruta por pastores, às proximidades da vila de Nazaré, no século XII. Aliás, de acordo com a tradição local, a imagem encontrada pelo caboclo Plácido dos Santos às margens do igarapé Murutucu, no início do século XVIII, é a "cópia fiel" da imagem da Vila de Nazaré. Diz o relato mítico que Plácido, após o seu achado, tentou levar a imagem para sua casa, mas sempre no dia seguinte à sua tentativa a santa reaparecia no lugar em que havia originalmente sido encontrada. Por fim, o governador da província da época fez uma última tentativa de estabelecer a imagem num outro nicho: o Palácio do Governo, permanecendo sob a vigília de soldados. No dia seguinte, da mesma forma, a santa reapareceria no lugar original, com gotas de orvalho e carrapichos pregados ao manto, atestando a longa e difícil caminhada do palácio do governo em direção ao igarapé. Este milagre representaria o desejo da santa de permanecer naquele local, sendo construída ali desde então uma ermida pelo próprio Plácido, melhorada mais tarde pela ação de um beato chamado Antônio Agostinho, que administrou a ermida em conjunto com o primeiro bispo do Pará (D. Bartolomeu do Pilar), desde 1721. Desta capela viria a sair em 1793 o primeiro Círio, certamente antecedido por procissões não oficiais nos anos anteriores. Seu percurso viria a representar o milagre do deslocamento da santa do Palácio do Governo ao local onde se instalaria em 1861 a paróquia de Nossa Senhora de Nazaré.

12 Sobre o sentido da troca entre homens e seres divinos (ou mesmo, o sentido amplo da troca, em diversos planos e sociedades humanas) ver Mauss, 1974 (especialmente, páginas 59 a 67).

13 Sobre os conflitos mais marcantes da história da Círio de Nazaré, ver Maués (2000).

14 Pela lei estadual $n^{\circ}$ 4.371, de 15 de dezembro de 1971, Nossa Senhora de Nazaré passou a ser considerada oficialmente como Padroeira do Pará e Rainha da Amazônia.

15 Da mesma forma, o Círio da Vila de Nazaré em Portugal é celebrado no mês de setembro.

16 A pedra fundamental da futura Basílica de Nazaré foi colocada em 24 de outubro de 1909. Só em 1923 terminaria a sua construção, com a inauguração do Altar-Mor.

17 Participam atualmente da procissão matinal do segundo domingo de outubro doze carros alegóricos: Barco dos Escoteiros, Barca Nova, Barca com Velas, Carro do Anjo Protetor da Cidade, Barca Portuguesa, Barca com Remos, Carro dos Milagres, Carro do Caboclo Plácido e quatro Carros dos Anjos. Estes carros foram sendo acrescidos à procissão ao longo do tempo desde o primeiro Círio, isto ocorrendo até nos Círios mais recentes (por exemplo, com a inserção do Carro do Caboclo Plácido no Círio de 2000). 0 conteúdo simbólico que reveste a inserção destes carros revela um repertório importante do processo de construção do significado histórico do Círio, que infelizmente não cabe discutir aqui por conta da limitação temática do texto. 
18 Para DaMatta, no entanto, o carnaval é um típico ritual de inversão da ordem social, em que se instala uma ideologia de communitas entre seus participantes e espectadores. Por sua vez, os eventos religiosos tenderiam à conciliação, ao reconhecimento e à permanência das diferenças sociais, colocadas em segundo plano em relação à experiência religiosa conduzida por este tipo de ritual, como propõe Turner (1974).

19 De acordo com Pierre Sanchis, arraial é uma antiga palavra portuguesa, usada para denominar acampamentos militares de reis medievais. Na órbita das festas religiosas, para Sanchis, "[o] arraial é o prado, o campo plantado de árvores, o entroncamento de caminhos, a avenida ou a praça que a festa anexou; é também o ajuntamento que aí se forma, a densidade social que aí se cria, o povo que aí se comprime, o 'nós' gratuito que aí se instala; é, enfim, o conjunto de atividades que aí se desenrolam" (1992:142).

20 Vale dizer que todos os Círios das cidades do interior do Pará contam atualmente com um arraial ao lado da Igreja, seguindo o modelo de feira e parque de diversões.

21 Segundo este autor, isto deu origem a dois tipos de espetáculos populares associados à festa de Nazaré: o teatro nazareno e as pastorinhas. Nesta obra, Moura (1997) apresenta uma descrição destes exemplos de dramaturgia popular associados ao Círio. Os croquis do arraial apresentados são dos anos de 1974 e 1975.

23 Aliás, a ocorrência de outros tipos de eventos marcados pela presença de estandes de exposição de produtos na cidade passou a ocupar nas últimas duas décadas este papel desempenhado pelo arraial nazareno.

24 Na região portuária, na confluência entre o Boulevard Castilhos França e a Avenida Presidente Vargas, que faz parte do trajeto da Transladação e da procissão principal.

25 No Círio de 2003 esta homenagem consumiu ao todo 3.500 dúzias de pistolas, segundo informações obtidas no sindicato dos estivadores.

Em 2003, o sindicato arrecadou das contribuições de seus integrantes para a homenagem o valor de 40 mil reais.

27 Profissionais contratadores e organizadores de festas articuladas entre donos de casas de festas e de aparelhagens. Os festeiros atuam como free-lancers no negócio das festas de brega, retirando uma porcentagem dos lucros dos eventos por sua iniciativa e por se responsabilizar pela administração in loco da festa. Destacam-se profissionalmente pela quantidade de contatos com os demais profissionais do circuito bregueiro e por contar com sua confiança. Na maioria das vezes, a carreira dos festeiros se inicia com a organização de pequenas festas de vizinhança nos bairros periféricos da cidade até o ponto em que o acúmulo de experiências, contatos e capital lhes permite adentrar profissionalmente o circuito bregueiro.

28 Como o aniversário de um festeiro local ou uma rua de lazer, promovida por associações de moradores, igrejas, escolas etc.

29 Em 2002, quando da campanha eleitoral para a presidência, os candidatos que vieram a Belém contrataram aparelhagens para os seus comícios. Por exemplo, a aparelhagem Tupinambá sonorizou o comício de Lula e o PopSom participou do comício de Anthony Garotinho.

30 Esta última denominada por um entrevistado como a "festa dos profissionais do brega": trabalhadores envolvidos nas apresentações de aparelhagens e nos serviços das casas de festa. 


\section{REFERÊNCIAS BIBLIOGRÁFICAS}

ALVES, Isidoro M. S. 1980. O Carnaval Devoto: um estudo sobre a Festa de Nazaré, em Belém. Petrópolis: Vozes.

AMARAL, Rita de Cássia. 1998. Festa à Brasileira: significados do festejar, no país que "não é sério". Tese de Doutorado. São Paulo: Universidade de São Paulo, Departamento de Antropologia.

COSTA, Antonio Maurício Dias da. 1999. “Domingos de Festa: a sociabilidade nas ruas de lazer". In M.A. D'Incao (org.) Sociabilidade: espaço e sociedade. São Paulo: Grupo Editores.

UFS. 2003. “Festa na Cidade: o circuito bregueiro de Belém do Pará". Tomo no 6: 107-136. São Cristóvão-SE: NPPCS/

CRUZ, Ernesto. 1952. Procissão dos Séculos (vultos e episódios da história do Pará). Belém: Imprensa Oficial do Estado do Pará.

1967. História do Pará, vol. I. Belém: Universidade Federal do Pará.

DaMATTA, Roberto. 1999. Carnavais, Malandros e Heróis: para uma sociologia do dilema brasileiro. $5^{a}$ edição. Rio de Janeiro: Guanabara Koogan.

DEL PRIORI, Mary. 1994. Festas e Utopias no Brasil Colonial. São Paulo: Brasiliense.

FERRÃO, Euzalina et alli. 1996. As Quadrilhas Roceiras de Belém e a Política Cultural da FUMBEL, no evento Rastapé Belém, 1996: uma análise do discurso. Trabalho do curso de especialização em Teoria Antropológica. Universidade Federal do Pará, datilo.

ISAMBERT, François-André. 1982. Le Sens du Sacré: fête et religion populaire. Paris : Les Éditions de Minuit.

JURANDIR, Dalcídio. 1960. Belém do Grão Pará. São Paulo: Livraria Martins Editora.

MAGNANI, José Guilherme. 1996. “Quando o Campo é a Cidade: fazendo antropologia na metrópole”. In J.G. C. Magnani \& L.L. Torres (orgs.) Na Metrópole: textos de antropologia urbana. São Paulo: Edusp/Fapesp.

$\overline{11-29 .}$ 2002. "De Perto e de Dentro: notas para uma etnografia urbana". Revista Brasileira de Ciências Sociais 17(49):

MAUÉS, Raymundo Heraldo. 2000. "Histórico do Círio de Nazaré". In J. da Silva (coord.) Círios de Nazaré. Belém: Graphitte.

MAUSS, Marcel. 1974. "Ensaio sobre a Dádiva. Forma e razão da troca nas sociedades arcaicas". In Sociologia e Antropologia. Tradução de Mauro W. B. de Almeida. São Paulo: Epu/Edusp.

MOMBELLI, Savino. 1976. Valores Religiosos do Círio de Nazaré. Belém: Universidade Federal do Pará.

MOREIRA, Eidorfe. 1971. Visão Geo-Social do Círio. Belém: Gráfica Universitária.

MOURA, Carlos Eugênio Marcondes de. 1997. O Teatro que o Povo Cria: cordão de pássaros, cordão de bichos, pássaros juninos do Pará. Belém: Secult/PA.

ROCQUE, Carlos. 1981. História do Círio e da Festa de Nazaré. Belém: Mitograph.

SANCHIS, Pierre. 1992. Arraial, Festa de um Povo: as romarias portuguesas. Lisboa: Dom Quixote. 
TRINDADE Jr., Saint-Clair C. 1997. Produção do Espaço e Uso do Solo Urbano em Belém. Belém: UFPA/ Naea/ Plades. TURNER, Victor. 1974. O Processo Ritual: estrutura e antiestrutura. Tradução de Nancy Campi de Castro. Petrópolis: Vozes.

VIANNA, Arthur. 1904. "Festas Populares do Pará: I - A Festa de Nazareth". Annaes da Biblioteca e Archivo Público do Pará, Tomo III. Belém: Typ. e encadernação do Instituto Lauro Sodré.

\section{Fontes Consultadas}

Anuário Estatístico do Município de Belém v. 5, 1998. Belém: Secretaria Municipal de Coordenação Geral do Planejamento e Gestão, 1999.

“Registro das Aparelhagens Sonoras de Belém". Polícia Civil do Pará/ Divisão de Polícia Administrativa. Seção de Diversões Públicas, 14 de janeiro de 2003.

Folheto de Informações:

“Círio de Nazaré: informações úteis e importantes". Belém: Diretoria da Festa de Nazaré, 2000.

Jornais:

O Liberal

Diário Oficial (Poder Executivo do Estado do Pará)

Revistas:

Época (6 de maio de 2002)

Pará Onde (número 7, outubro de 2001)

Brega Mania (números 1, 2, 3, 4, 5 e 6 - de janeiro a novembro de 2001)

Jornal/Revista Contexto (número 17, primeira quinzena de fevereiro de 2002) 


\section{A Festa dentro da Festa: Recorrências do modelo festivo do circuito bregueiro no Círio de Nazaré em Belém do Pará}

RESUMO

Ao considerar a forma como se apresenta atualmente o Círio de Nazaré, ponto alto do calendário festivo anual de Belém, torna-se visível a presença nos seus interstícios de um modelo festivo consolidado histórica e espacialmente na cidade desde o início dos anos 80: o circuito das festas de brega. Conjugando a atuação empresarial (dos donos das casas de festa e de empresas de sonorização) ao mundo festivo e de lazer dos bairros periféricos da cidade, o circuito das festas de brega se faz presente na órbita ou mesmo se aproxima do interior do grande evento religioso. Este texto busca discutir as formas pelas quais as "festas de brega" têm se adequado à dinâmica da Festa de Nazaré, considerando sua abrangência física e simbólica na cidade. $O$ artigo sugere que a experiência festiva do público do circuito bregueiro se associa à prática festiva dos grandes eventos urbanos, reinventando o sentido do "festejar típico" da população de Belém.

PALAVRAS-CHAVE: modelo festivo, circuito bregueiro, Círio de Nazaré, prática festiva, sociabilidade.

\section{The Party Inside the Party: The festive model of the "bregueiro circuit" within the Círio de Nazaré Festival in Belém do Pará}

\section{ABSTRACT}

Considering the way by which Círio de Nazaré presents itself nowadays, at the height of the annual festive calendar in Belém do Pará (Brazil), it is remarkable to see the combined presence of a festive model historically and spatially materialized in town since the 80 's: the brega feasts circuit. Linking entrepreneurial initiative (the owners of clubs and machine-sound enterprises) to the festive and leisure ambiance in the outskirts of town, the brega feasts circuit is present surrounding or reaching the core of the great religious event. This article is intended to discuss the modes by which the "brega feasts" have matched up the dynamics of Nazaré Festival, considering its physical and symbolic scope in town. The departure point is that the festive experience absorbed by attendants to the bregueiro circuit is connected to the festive practice of great urban events, reinventing the meaning of the typical way of public celebration in Belém. KEY WORDS: festive model, bregueiro circuit, Círio de Nazaré, festive practice, sociability. 